\title{
Bacterial growth in media mimicking the high salt and alkalinity of extreme kazakhstan environments results in production of antimicrobial compounds in soil actinomycetes isolated from these extremophile locations
}

\author{
Jill Roberts' ${ }^{1}$, Lyudmila Trenozhnikova², Lylah Seaton ${ }^{3}$, Ami Patel $^{3}$, Colton Faza ${ }^{3}$, Jacqueline Whitaker ${ }^{4}$, Christen Mayer ${ }^{4}$ and \\ Azliyati Azizan ${ }^{3 *}$ \\ *Correspondence: aazizan@health.usf.edu \\ 'Department of Environmental and Occupational Health, USF College of Public Health, Tampa, Florida, USA. \\ ${ }^{2}$ Institute of Microbiology and Virology, Almaty, Kazakhstan. \\ ${ }^{3}$ Department of Global Health, USF College of Public Health, Tampa, Florida, USA. \\ ${ }^{4}$ Florida Hospital, Tampa, Florida, USA.
}

\begin{abstract}
Increasing antibiotic resistance among multidrug resistant pathogens necessitates the search for newer antimicrobials. Streptomyces historically produce the largest number of antibacterials and herein we describe isolation of antagonists from extremophiles using unusual culture media. Antagonists or antimicrobials produced under extremophile environmental conditions demonstrated activity against MRSA from Kazakhstan and the United States.
\end{abstract}

Keywords: Extremophiles, antagonists, antibacterial, antibiotics, HA-MRSA

\section{Introduction}

Staphylococcus aureus colonization of the nose is common in the United States with an estimated $30 \%$ of the population carrying the organism asymptomatically [1]. However, S. aureus is an opportunistic pathogen accounting for as many as 478,000 hospitalizations as recently as 2005 , more than half of which were due to methicillin-resistant S. aureus (MRSA) [2]. In fact, MRSA is the leading cause of multidrug resistant (MDR) hospital-associated infections in the United States [3]. MDR infections are associated with increased mortality, cost of care, and length of hospital stay $[4,5,6,7]$. Few antibiotic therapies are currently available to treat these multidrug-resistant pathogens and strains are increasingly insusceptible to new therapies.

Previously our laboratory has demonstrated that a compound produced by Streptomyces isolated from the soils of Kazakhstan possesses anti-Staphylococcal activity [8]. Historically, Streptomyces has been shown to be the largest antibiotic-producing genus [9] and consequently most clinically-used antibiotics are natural products or synthetic derivatives from the soil actinomycetes $[10,11,12]$. Mathematical modeling suggests that less than $10 \%$ of the antimicrobial compounds capable of being produced by Streptomyces $s p$. have been discovered $[9,11]$. Theories for the decline in soil actinomycetes-derived antibiotic discovery include decreased screening efforts and lack of focus on culture conditions, and these are the basis of the current study.

Because our earlier study suggested that antimicrobials may be produced by actinomycetes when grown under stress conditions, we collected 5,936 strains from Kazakhstan soil and marine environments exhibiting high salinity and/or alkalinity (unpublished: Institute of Microbiology and Virology Report). From this, a total of 2,019 isolates which were morphologically consistent with actinomycetes were grown on variations of Bennett's agar, which differed by salt and $\mathrm{pH}$ concentration to approximate the extremophile's environmental conditions. The culture conditions used included three variants of Bennett's agar; a neutral medium of pH 7.2 (medium 1), a saline medium with $5 \% \mathrm{NaCl}$ added (medium 2), and an alkaline medium with $0.5 \% \mathrm{Na}_{2} \mathrm{CO}_{3}$ of pH 9.0 (medium 3). Potential antimicrobials were then isolated from the culture broths using extraction and chromatography methods as previously described [8]. A total of 424 of the extremophile strains produced antagonists, the majority of which exhibited inhibition against a Kazakhstan hospital-associated MRSA (HA-MRSA), when grown in extreme conditions (data not shown) using the standard disk diffusion assay [13]. We propose that actinomycetes may produce novel antimicrobials when cultivated under stress conditions and that these compounds have not previously been recognized due to the use of neutral culture conditions. The ability to produce antimicrobial compounds under stress conditions may provide the Streptomyces with an ecological advantage in extreme environments such as those found in Kazakhstan. We propose that anti-MDR antibiotics may be developed from these natural producers much like those currently in development from other unusual sources $[10,11,13,14]$

(c) 2013 Azizan et al; licensee Herbert Publications Ltd. This is an Open Access article distributed under the terms of Creative Commons Attribution License (http://creativecommons.org/licenses/by/3.0). This permits unrestricted use, distribution, and reproduction in any medium, provided the original work is properly cited. 
Roberts et al. Journal of Pharmaceutical Technology \& Drug Research 2013, http://www.hoajonline.com/journals/pdf/2050-120X-2-14.pdf

Table 1. Inhibition of Kazakhstan and US HA-MRSA by Actinomycetes Antagonists.

\begin{tabular}{|c|c|c|c|c|}
\hline \multirow{3}{*}{$\begin{array}{l}\text { Antagonist \# } \\
\text { and Source (pH) }\end{array}$} & \multicolumn{3}{|c|}{$\begin{array}{l}\text { Zone of Inhibition } \\
\text { (Kazakhstan HA-MRSA) } \\
(\mathrm{mm})\end{array}$} & \multirow{3}{*}{$\begin{array}{l}\text { United States HA-MRSA } \\
\text { Zone of Inhibition }{ }^{\mathrm{e}}(\mathrm{mm})\end{array}$} \\
\hline & \multicolumn{2}{|c|}{ Growth } & \multirow{2}{*}{$\begin{array}{l}\text { Media } \\
3^{c}\end{array}$} & \\
\hline & $1^{\mathrm{a}}$ & $2^{\mathrm{b}}$ & & \\
\hline $2-2 \operatorname{mud}(9.1)$ & 0 & 18 & NG & 0 \\
\hline $\begin{array}{l}\text { 6-12 rhizosphere } \\
(8.6)\end{array}$ & 0 & 25 & NG & 0 \\
\hline $\begin{array}{l}\text { 18-7 sandy soil } \\
(10.0)\end{array}$ & 13 & 44 & NG & 0 \\
\hline $19-25$ soil $(9.3)$ & 0 & 35 & 0 & 11.5 \\
\hline 33-1 mud (9.6) & $N^{d}$ & 49 & 39 & 10.0 \\
\hline $\begin{array}{l}\text { 36-3 meadow } \\
\text { soil }(8.3)\end{array}$ & 10 & 24 & 23 & 0 \\
\hline $\begin{array}{l}\text { 41-8 saline soil } \\
(10.0)\end{array}$ & 11 & 29 & 15 & 7.0 \\
\hline $\begin{array}{l}48-29 \text { sandy soil } \\
(10.0)\end{array}$ & 0 & 32 & 22 & 20.5 \\
\hline $\begin{array}{l}\text { 51-9 rhizosphere } \\
(9.5)\end{array}$ & 10 & 46 & 10 & 0 \\
\hline $\begin{array}{l}58-22 \text { rhizosphere } \\
(8.9)\end{array}$ & 0 & 18 & 14 & 22.5 \\
\hline 72-1 soil (9.6) & 0 & 50 & NG & 0 \\
\hline 96-1 soil (8.6) & 11 & 26 & 19 & 0 \\
\hline Q4-39 soil (10.0) & 0 & 16 & 15 & 0 \\
\hline $\begin{array}{l}\text { Y-45 rhizosphere } \\
(9.8)\end{array}$ & 0 & 20 & 16 & 0 \\
\hline
\end{tabular}

${ }^{a}$ Growth Medium 1 = Modified Bennett's pH=7.2.

${ }^{\mathrm{b}}$ Growth Medium 2 = Modified Bennett's pH=7.2, 5\% NaCl.

${ }^{c}$ Growth Medium 3 = Modified Bennett's pH=9.0, 0.5\% $\mathrm{Na}_{2} \mathrm{CO}_{3}$.

${ }^{\mathrm{d}} \mathrm{NG}=$ No growth of the Actinomycetes producer.

${ }^{\mathrm{e}}$ Zone of Inhibition for US HA-MRSA reported is an average of multiple disk diffusion assays (DDA's).

Notes on Growth Medium:

Modified Bennett's Growth Media $1^{\mathrm{a}}, 2^{\mathrm{b}}$ and $3^{\mathrm{c}}$ comprised of glucose $(0.2 \%)$, peptone $(0.2 \%)$, yeast extract $(0.1 \%)$, and agar $(2 \%)$, were used to grow actinomycete strains and incubated at $28^{\circ} \mathrm{C}$, and growth was checked after 1-2 weeks incubation. Purified isolates were investigated in antibacterial tests against Kazakhstan HA-MRSA using the standard disk diffusion assay (DDA); strains with positive anti-MRSA activities were chosen for preparation of Kazakhstan (KZ) extracts.

Notes on Antagonistic KZ extract antibacterial testing against Kazakhstan and United States HA-MRSA:

Fourteen KZ extracts (first column of Table 1 labeled as "Antagonistic \#") containing components with antibacterial activities shipped from Kazakhstan were tested in antagonistic tests against United States HA-MRSA grown on Mueller-Hinton agar plates, using standard Kirby-Bauer disk diffusion assay (DDA). Dilution of KZ extracts and antibacterial testing were performed using similar conditions for HA-MRSA isolates from Kazakhstan and United States, using our previously reported methods [8]. Sterile disks containing $10 \mu \mathrm{g} / \mathrm{mL}$ of crude powder of $\mathrm{KZ}$ extracts were placed on fresh plates of the Mueller-Hinton agar seeded with bacterial suspensions at a cell density of $5 \times 10^{5}$ $\mathrm{CFU} / \mathrm{ml}$ of overnight cultures of the test.

HA-MRSA strains. The diameters of the zones of inhibition of growth $(\mathrm{mm})$ around the disks measured after incubation periods of $18 \mathrm{~h}$ at $37^{\circ} \mathrm{C}$ presented are average values from triplicate experiments. and that further screening of these compounds is warranted.

Geographical studies of the distribution of epidemic MRSA have demonstrated that the prominent strains in the United States differ from those found in the Kazakhstan region $[15,16,17]$ suggesting that antibiotic efficacy is not equivalent worldwide. Therefore we selected fourteen of the purified anti-staphylococcal compounds produced by the Kazakhstan extremophiles for disk diffusion susceptibility testing using HA-MRSA in the United States. Table 1 lists the fourteen antimicrobial products tested, the stress conditions used to produce the antagonists, the environment from which the actinomycetes producer was isolated, and the observed zone of inhibition against the Kazakhstan HA-MRSA isolate. Sterile disks containing the Kazakhstan antimicrobials were prepared as previously described [8] and disk diffusion susceptibility assay against HA-MRSA was performed using the standard Kirby-Bauer protocol [18]. While the fourteen antagonists tested displayed varied degrees of inhibition against Kazakhstan HA-MRSA, less than half (5 of 14) inhibited US HA-MRSA (Table 1). These data are consistent with the known geographical differences in antibiotic resistance profiles namely in that MRSA strains from the United States are resistant to more antibiotics than those in the Kazakhstan region. These data suggest that the screening method used here in is a valuable tool in identifying potential antibiotics of worldwide utility and future work will include the continued susceptibility testing of the compounds against a wider variety of Staphylococcus isolates.

Studies suggest that the classical methodology of screening natural products, particularly those produced by bacterial sources for antibacterial properties is far from reaching its potential [10] despite a decline in the use of these methods. Antibiotic production from natural products may see resurgence as few new synthetic compounds are available and genomic approaches have been largely disappointing. Our data suggest that antagonists produced by actinomycetes when cultivated under stress conditions inhibit MDR strains of Staphylococcus aureus. We therefore suggest that high throughput screening of additional Kazakhstan extremophile products incorporating inhibition assays against global MDR isolates is warranted.

\section{Competing interests}

The authors declare that they have no competing interests.

\section{Authors' contributions}

JR analyzed the data and wrote the manuscript. LT performed screening of antibiotic producers, prepared and provided extracts from Kazakhstan. LS optimized laboratory experimental protocols and provided technical supervision in the laboratory. APand CF conducted laboratory experiments, analyzed data and contributed to manuscript preparation. JW and CM provided MRSA clinical isolate and oversight regarding culture and growth conditions. AA as the Principal Investigator provided oversight for the project including laboratory experiments, data analyses and maintained communications with members of the collaborating team. All authors provided intellectual input, read and approved the final manuscript. 


\section{Acknowledgement}

The Authors would like to thank the Institute of

Microbiology and Virology in Almaty, Kazakhstan, the

University of South Florida (USF), and Florida Hospital

Tampa, for supporting the collaboration, and the

USF College of Public Health for the funding (Early

Career Investigator Award) to support this work.

\section{Publication history}

Received: 29-Dec-2012 Revised: 25-Mar-2013

Accepted: 28-Mar-2013 Published: 13-Apr-2013

\section{Reference}

1. Gorwitz RJ, Kruszon-Moran D, McAllister SK, McQuillan G, McDougal LK, Fosheim GE, Jensen BJ, Killgore G, Tenover FC and Kuehnert MJ: Changes in the prevalence of nasal colonization with Staphylococcus aureus in the United States, 2001-2004. J Infect Dis 2008, 197:1226-34. | Article | PubMed

2. Klein $E$, Smith DL and Laxminarayan R: Hospitalizations and deaths caused by methicillin-resistant Staphylococcus aureus, United States, 1999-2005. Emerg Infect Dis 2007, 13:1840-6. | Article | PubMed Abstract | PubMed Full Text

3. Hidron AI, Edwards JR, Patel J, Horan TC, Sievert DM, Pollock DA and Fridkin SK: NHSN annual update: antimicrobial-resistant pathogens associated with healthcare-associated infections: annual summary of data reported to the National Healthcare Safety Network at the Centers for Disease Control and Prevention, 2006-2007. Infect Control Hosp Epidemiol 2008, 29:996-1011. | Article | PubMed

4. Cosgrove SE and Carmeli Y: The impact of antimicrobial resistance on health and economic outcomes. Clin Infect Dis 2003, 36:1433-7. | Article | PubMed

5. Cosgrove SE, Qi Y, Kaye KS, Harbarth S, Karchmer AW and Carmeli $Y$ : The impact of methicillin resistance in Staphylococcus aureus bacteremia on patient outcomes: mortality, length of stay, and hospital charges. Infect Control Hosp Epidemiol 2005, 26:166-74. | Article | PubMed

6. Engemann JJ, Carmeli Y, Cosgrove SE, Fowler VG, Bronstein MZ, Trivette SL, Briggs JP, Sexton DJ and Kaye KS: Adverse clinical and economic outcomes attributable to methicillin resistance among patients with Staphylococcus aureus surgical site infection. Clin Infect Dis 2003, 36:592-8. | Article | PubMed

7. Klevens RM, Morrison MA, Nadle J, Petit S, Gershman K, Ray S, Harrison LH, Lynfield R, Dumyati G, Townes JM, Craig AS, Zell ER, Fosheim GE, McDougal LK, Carey RB and Fridkin SK: Invasive methicillin-resistant Staphylococcus aureus infections in the United States. JAMA 2007, 298:1763-71. | Article | PubMed

8. Trenozhnikova LP, Khasenova AK, Balgimbaeva AS, Fedorova GB, Katrukha GS, Tokareva NL, Kwa BH and Azizan A: Characterization of the antibiotic compound no. 70 produced by Streptomyces sp. IMV70. ScientificWorldJournal 2012, 2012:594231. | Article | PubMed Abstract | PubMed Full Text

9. Watve MG, Tickoo R, Jog MM and Bhole BD: How many antibiotics are produced by the genus Streptomyces? Arch Microbiol 2001, 176:386-90. | Article | PubMed

10. Clardy J, Fischbach MA and Walsh CT: New antibiotics from bacterial natural products. Nat Biotechnol 2006, 24:1541-50. | Article | PubMed

11. Fischbach MA and Walsh CT: Antibiotics for emerging pathogens. Science 2009, 325:1089-93. | Article | PubMed Abstract | PubMed Full Text

12. Newman DJ and Cragg GM: Natural products as sources of new drugs over the 30 years from 1981 to 2010. J Nat Prod 2012, 75:31135. | Article | PubMed

13. Hartkoorn RC, Sala C, Neres J, Pojer F, Magnet S, Mukherjee R, Uplekar S, Boy-Rottger S, Altmann KH and Cole ST: Towards a new tuberculosis drug: pyridomycin - nature's isoniazid. $E M B O \mathrm{Mol}$ Med 2012, 4:1032-42. | Article | PubMed Abstract | PubMed Full Text

14. Baltz RH: Marcel Faber Roundtable: is our antibiotic pipeline unproductive because of starvation, constipation or lack of inspiration? J Ind Microbiol Biotechnol 2006, 33:507-13. | Article | PubMed

15. Goncharov AE, Olsson-Liljequist B, Zueva LP, Kolodzhieva VV, Khoroshilov $V$ and Satosova NV: [Epidemic strain of methicillinresistant Staphylococcus aureus in hospitals of Saint-Petersburg]. Zh Mikrobiol Epidemiol Immunobiol 2010, 24-9. | Article | PubMed

16. McDougal LK, Steward CD, Killgore GE, Chaitram JM, McAllister SK and Tenover FC: Pulsed-field gel electrophoresis typing of oxacillinresistant Staphylococcus aureus isolates from the United States: establishing a national database. J Clin Microbiol 2003, 41:5113-20. I Article | PubMed Abstract | PubMed Full Text

17. Vorobieva V, Bazhukova T, Hanssen AM, Caugant DA, Semenova $\mathrm{N}$, Haldorsen BC, Simonsen GS and Sundsfjord A: Clinical isolates of Staphylococcus aureus from the Arkhangelsk region, Russia: antimicrobial susceptibility, molecular epidemiology, and distribution of Panton-Valentine leukocidin genes. APMIS 2008, 116:877-87. Article | PubMed

18. Bauer AW, Kirby WM, Sherris JC and Turck M: Antibiotic susceptibility testing by a standardized single disk method. Am J Clin Pathol 1966, 45:493-6. | PubMed

\section{Citation:}

Roberts J, Trenozhnikova L, Seaton L, Patel A, Faza C, Whitaker J, Mayer C and Azizan A: Bacterial growth in media mimicking the high salt and alkalinity of extreme kazakhstan environments results in production of antimicrobial compounds in soil actinomycetes isolated from these extremophile locations. journal of Pharmaceutical Technology and Drug Research 2013, 2:14. http://dx.doi.org/10.7243/2050-120X-2-14 